\title{
To the question of the limits of progress: Is singularity possible?
}

\section{G. Shestakova}

Norwich University, VT, US, 158 Harmon Drive Northfield, VT, US 05663

For citation: Shestakova I. G. To the question of the limits of progress: Is singularity possible? Vestnik of Saint Petersburg University. Philosophy and Conflict Studies, 2018, vol. 34, issue 3, pp. 391-401. https://doi.org/10.21638/11701/spbu17.2018.307

This article explores the idea accepted in the social philosophy at the turn of $20^{\text {th }}-21^{\text {st }}$ century, that the exponential growth of the speed of progress results in the technological singularity. In natural science, the process characterized by initial exponential acceleration typically reaches a saturation phase and then develops according to another mathematical low. This does not mean to imply that the initial phase continues uninterruptedly, but may indeed consist of early outflows to the saturation phase and transition to plateaus of speed. If such a description is typical in natural science, would not predictions for science and technology, in general, be characterized by perhaps not apocalyptic conclusions but the appearance of such singularities? Would it not be expected from processes in natural science that the acceleration of scientific progress might be replaced by deceleration and a complete stoppage of acceleration? Mechanisms for retarding acceleration of info-communications are revealed in the adaptive capabilities of individual approaching planning horizons, and specifically in the investment in the military-industrial complex, which has its own logic representing a direct driving force for progress in the civil sphere. At the same time, despite possible dampening of acceleration of progress in science and technology, progress itself and social transformations will not stop, and will not even slow down, but continue with the speed, which will become permanent.

Keywords: social philosophy, scientific and technical progress, infocommunication, development speed, planning horizon, exponent, singularity, determinism, limits of progress.

\section{Introduction. Thinking about singularity}

The present-day reality is characterized by an incredible acceleration of scientific and technological progress, especially in the field of info-communications, and as a result abrupt changes in socio-economic life, occurring many times during the lifetime of one generation, and it seems to us that this will continue indefinitely.

Modern generation has got accustomed to such an incredible speed of progress. Ongoing scientific and technological progress has become an integral and, moreover, an essential component of our being.

Considering the pace of scientific and technological progress, which is determined mainly by the development of infocommunication technologies at this historical stage, we conclude that accelerated development is ongoing. On the other hand, however, its speed

(C) Санкт-Петербургский государственный университет, 2018 
has already reached the level, on which we are entering such an area of radically affecting the most important aspects of people's lives achievements of scientific and technological progress, that occur before our eyes one after another, that is, many times during the lifetime of one generation [1, p.75]. Such a situation has developed for the first time in the history of mankind. An important question that mankind is asking at an absolutely unprecedented moment of its existence is what will happen next and where will this acceleration lead to?

The main track from the birth of the first technologies of information exchange to the digital world is a line that can eventually be represented by an exponential curve or even a function stronger than an exponential, but according to the principle of the unpredictability of reality, the further ontology of info-communication cannot be outlined.

It would seem that nothing will stop this infinitely accelerating movement. Building a forecast for the future proceeding from the continuation of the present trends, we will undoubtedly come to the conclusion of an even greater acceleration, and so on ad infinitum. Often (this is especially true for the field of the Humanities), if one wants to say that something is developing quickly, they say that it develops exponentially.

Many experts predict the further development of the scenario of this acceleration of progress in the form of outflow into a singularity. Especially controversial was the opinion of the Google technical director - the famous technological futurist Ray Kurzweil, who argues that technological progress is not linear, but exponential. And, in his opinion, exponential growth is the main property of the evolutionary process [2, p. 278].

Exponential dependence is a widespread dependence on time of various processes observed by natural science: ignition of the discharge, the inclusion of electrical circuits (the establishment of the current in the electrical network), the establishment of the oscillation of the pendulum, the exponential dependence of mortality on age. The exponential function describes the models of population growth, the growth of resource consumption as a result of the increase in the number of people, as well as Moore's well-known law.

By prolonging the exponent - a trend of the observed acceleration in the modern development in the field of info-communications, - we will undoubtedly come to the idea of singularity as the ultimate outcome of this process [2-6].

Such statements are possible in philosophy. What does scientific knowledge tell us about this? In our paper [7, p.47-51], we had considered some examples of the limits of scientific and technological development for individual industries, given by the fundamental laws of nature. Such limits of development operate only in separate directions, which do not mean the limit of the development of scientific and technological progress as a whole.

\section{A typical example from natural science}

Turning to typical examples from physics and other areas of natural science, it should be noted that if something increases with acceleration, this does not mean that this acceleration will take place perpetually.

For physical processes, it is characteristic that in the initial stages their velocity increases exponentially with time. However, over time, the growth rate slows down and stops. This only means that the speed does not increase any more. At the same time, the process does not stop, it comes with a constant (perhaps, huge) speed, which is gathered. 

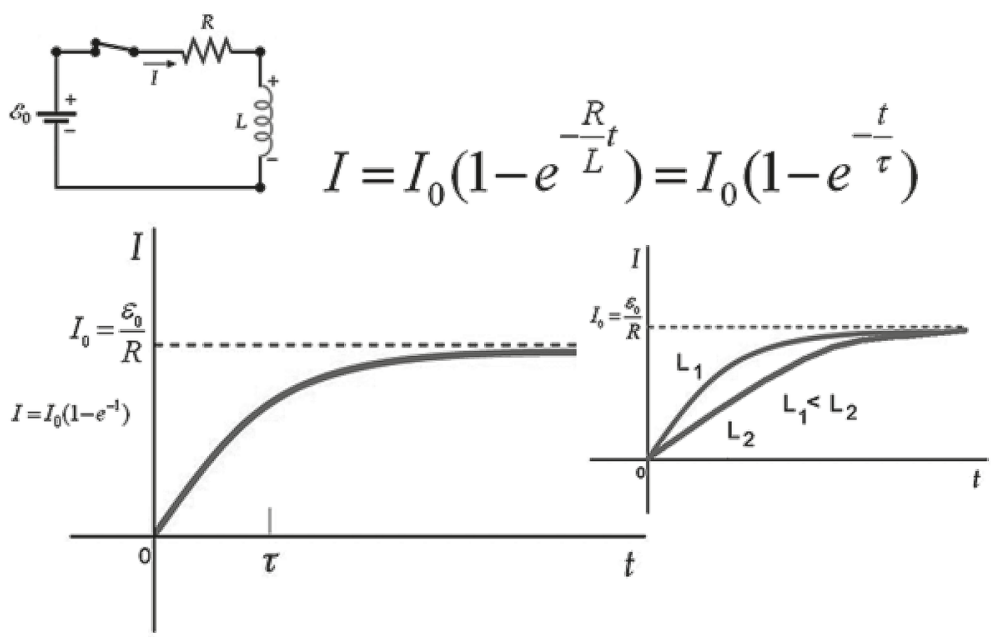

Fig. 1. Establishment of current in the electrical circuit containing inductivity at it its switching on

For example, this is how the current is set, when the electrical circuit containing the inductance is switched on. This typical physical process, evolving in time, is a combination of an exponential with a constant (Fig. 1).

\section{Development in the exponent. An attempt to predict the future}

If we observe this process and at the moment of observation we are in the area, where the function is described by the exponent and the acceleration is clearly traced, then for the inexperienced observer the idea of the future of this process is natural (that is, correct from the point of view of common sense) as prolongation of the trend of the observed process. Therefore, such an observer with a high probability of prediction comes to the continuation of the acceleration of development.

However, the observer is mistaken. The real continuation of the curve can only be predicted by the conceivable principle of determinism and understanding the dynamics of natural processes, since in reality (as reflected in natural science or according to the laws of nature) the process of acceleration ceases in the observable future.

Here it is important to point to a stable expression - the "current establishment", which characterizes the transitional process from the beginning of the function to the achievement of a stable state. The presence of it indicates that the process of development occurs only on small intervals of time. The process of movement sooner or later comes to a "stable state", and this will happen not in some incredibly distant future. Everything happens (if this exponent describes the process occurring in time) on scales proportional to $\tau$ ( $\tau-$ characteristics of time - the time for which the exponent grows in $\mathrm{e}=2.7$ times.).

That is, the function is described by an exponential law only for small intervals of time. If the time $\tau$ is infinitely large, the development is infinitely slow, since the development is 2.7 times in an infinitely large time interval. Therefore, if for the observer the exponents of the change occur quickly, then saturation will occur quickly. 


\section{The prediction in the field of society}

Let us try to transfer this knowledge to social reality, to comprehend it in the perspective of social philosophy. If, for example, the considered above current is the amount of electricity flowing per time unit through the conductor cross-section, then in our case it is the speed of progress, i.e., the number of events occurring per time unit for which we take the average time of a person's social life.

The problem is that for the processes, that happen in natural science, determinism (which means one hundred percent in classical Newtonian physics) normally takes place. In particular, the determinism of physics occurs due to the complete reproducibility of technologies based on physical principles.

The idea of absolute determinism was postulated by P. S. Laplace: if we can fix the current state, then we can accurately predict what was before and what will happen after [8].

Singularity is also found in theories about demographic development. For example, Malthus predicted such a singularity - the exponential growth of the human population with limited resources [9].

In the XIX century, the principles of determinism appeared in various scientific fields. They were transferred to the idea of the origin of man (Darwin). Earlier, Marx applied the principles of determinism to the stochastic movements in society. And despite the fact that social processes are incommensurably more complex than physical ones, and social technologies, as experience has shown, are practically non-reproducible, we meet many adherents of the application of the idea of determinism in the social sphere [10-17].

Determinism, as applied to scientific and technical progress, leads to the theory of singularity. Starting from the observed acceleration of development of info-communications technologies, a further scenario of this acceleration of progress is predicted in the form of outflow into a singularity. This, as we have indicated above, is the forecast that Kurzweil makes [2].

\section{Is singularity possible?}

It should be noted that not a single sociological forecast of outflow into singularity has come true yet. This is why we continue to exist. Singularity will most likely lead to the end of mankind, to the apocalypse.

Singularity exists in theories. In mathematics, it is a commonplace. In natural sciences, however, to obtain the result that goes to infinity, as a rule, makes one suspect an incorrect solution of the problem. Faced with infinity, the scientist considers it as a mistake by default: a technical error, or an incorrect statement of the problem, or going beyond the limits, where these assumptions are correct ${ }^{1}$. Hence the question: why should the progress in infocommunications go further into a singularity? Why, as we have seen in our current example, it will not slow down and go into the developing phase with

\footnotetext{
${ }^{1}$ In this case, everyone knows the example of a theory, in which it is possible to obtain singularity as singularity - the general theory of relativity. Einstein, like any other scientist who had faced with infinity, tried to overcome it. Ultimately, these singularities were recognized as a real physical object - the black holes. If not for this fact, one could say that singularity is absurd; however, in the case of GRT, it is recognized as possible.
} 
a constant, already achieved speed (analogous to the establishment of a stationary current in our example, see Fig. 1).

Turning to the most famous example - the predictions of Malthus regarding the growth of mankind according to the exponential law [9], it should be noted that he deduces his forecast from the observed fact - the growth of population. Consequently, this is not a prediction at all, but an arithmetic calculation of the function of time, which is described by an exponential. It is clear that if a graphic shows an exponent, then there will come such a time when growth will become inadequate to resources. You can calculate the time when there will be problems with food resources, when there will be a shortage of water and after which period of time there will be a problem with the land - when people will reach such a growth of population that they will occupy every square meter of land or even stand shoulder to shoulder. Mathematics will endure everything...

However, Malthus himself pointed to the mechanisms that limit singularity - they are wars and diseases that provide balance. Malthus's examples of possible mechanisms, how to contain the singularity (more precisely, disharmony and apocalypse) do not contain anything new. He recognizes the intraspecific struggle as an important mechanism for regulating the population. We observe these mechanisms that inhibit the singular growth of species, and in the animal world, where at the top of the food chain there are humans and some other beasts. In such high-ranking animals, intraspecific fighting is one of the regulators. The struggle for resources (for example, to protect one's territory) becomes stronger expressed. In addition, large, dominant animals are less likely to breed, their fertility is minimized due to the domination of species. All this, in general, is applicable to history. However, there are examples of developments on the "undivine program", which means that in history there is also a trend of "anti-harmony" - for example, the spread of imported rabbits in Australia [18]. Galapagos Islands, in addition to the concept of Charles Darwin, which was apparently conceived when visiting these islands, are also known for the incredible spread of goats brought to the island by pirates and fishermen, as well as various plant species. To combat invasive species [19], it is often necessary to apply "undivine" restraining mechanisms.

The Bible is full with the description of such restraining mechanisms. God himself uses them to help his people in the struggle for resources on the scale of the small land of Palestine, to mention, for example, the requirement to cut out all those living in fertile areas with their wives and children.

In fact, Malthus was wrong in his predictions. Wars did not limit the growth of the population. Diseases (at least in the form of a pandemic) were defeated, and disharmony in the ratio of resources and population growth stopped. His prediction of the linear development of the resource base is also erroneous since scientific and technological achievements lead not to a monotonous, but to a critical development. For example - no matter how we relate to these achievements, - achievements in genetics and the development of chemistry led to a breakthrough in the development of crops.

Malthus, despite his mistakes, could be still useful in discerning the mechanisms that restrain the endless growth of the population. Kurzweil, speaking about the infinite exponential scientific and technological progress (technological singularity), does not indicate the limits of growth, but seriously discusses the inevitable future [2]. 


\section{Are the mechanisms for deceleration in the scientific and technological progress possible in general?}

It should be noted that the main and perhaps the only stimulus for scientific and technological development is profit or economic feasibility. We can find an indication for this, for example, in the works of A.Smith, in the opinion of which "the consideration of his own private profit, is the sole motive which determines the owner of any capital to employ it either in agriculture, in manufactures, or in some particular branch of the wholesale or retail trade" [20, p.354]. So, investments in scientific and technological progress are possible only in case of receiving an obvious profit.

Profit as the main motivating factor of scientific and technological development is associated with both economic laws and with human nature. This obviously imposes new possible limitations on the unrestrained acceleration of scientific and technological development, because the speed of progress is already great, and if the acceleration promised by the trends occurs, it becomes irrelevant to produce something new in this rapid development, because if a new product appears too often, it becomes unprofitable. There must be a certain time between events, but because of the acceleration observed at the moment, it continues to decrease. This decrease in time intervals, in turn, has a limit due to human adaptability and economic expediency.

The specific minimum interval between innovations is a question that should rather be addressed to experts-marketers. In the production of consumer goods, a modern enterprise is not conceivable without a strategic department dealing with the economic prospects of the proposed development. In the competence of such a department, the conclusion about the frequency of new developments on the market for attracting due attention, which can provide a profit. This attention is directly related to the possibilities of human adaptation. It follows that the scale of the economically viable time that has to pass between the appearances of new products in this segment is measured not in seconds and not in minutes. The scale of the maximum possibility, as one can imagine, is measured by several events per year (we mean scientific and technological progress in different directions). Acceleration approaches its limit in the case of an irrational increase in it to values that a person can no longer absorb. Consequently, inhibition in this case greatly depends on the very nature of man.

The possibility of reducing the acceleration of progress is seen not only in human adaptation but also in many other factors, for example, in restrictions of the growth of population.

On the other hand, scientific and technological progress does not take place on its own. On the background, there are specific mechanisms - from an invention, the project of which emerged in the scientist's mind, to its actual embodiment. In this chain of realization of the idea, investments (possible in the case of potential benefits), production and planning are in demand. From the idea to realization and development up to publication, as a rule, many years and sometimes decades pass. However, in a rapidly developing milieu, the planning horizon narrows down [1]. When it is impossible to plan and predict, everything becomes unpredictable. Here we either face singularity, when nothing can be predicted, or we are close to saturation (to the limit) of the speed of progress. A potential consequence may be the reduction in investments in this area, because if the horizons of forecasting become too close, then, the incentives that drive progress to disappear, and investments disappear [21].

Understanding this makes it possible to predict the halt in the growth of the rates of scientific and technological progress. Most likely, this attenuation will occur automati- 
cally. Scientific and technological progress will not be hampered specially, despite some attempts to call for this (see $[22 ; 23]$ ).

Thus, in the contemporary world, we see changes associated with the transition of the border, when in the life of one generation everything is repeatedly transformed and these speeds are already difficult to adapt. $\Delta$ / the delta of possible acceleration of progress still exists, but the current speed of progress already predicts a possible limit for it, related both to human nature (the adaptive possibility) and to the economic inexpediency: the disharmony of producing new and the ability to buy. Perhaps we are already close to this point. As soon as the speed increases so that the timing of forecasting will become unreasonably small, the investment flow in the progress of infocommunications will noticeably decrease if it does not decrease to a minimum. At least if we talk about products of civil purpose in a liberal economics, this is an obvious mechanism for the transition of the exponential curve, which characterizes the acceleration of progress, to the saturation phase.

\section{Military competition as a factor of technological growth. Investments in a military-industrial complex}

At the same time, it is necessary to distinguish the area where development occurs under the influence of other driving forces - this is the sphere of military confrontation. There is another logic that does not take into account considerations of common sense: large amounts of money can be invested in the development of specific threats (real or specially invented by the military lobby).

Today this competition goes largely into cyberspace. In December 2016, the Russian President Vladimir Putin signed a decree [24], which thoroughly considers information and technical effects.

In the end, this may be the future of accelerating progress, since military development does not necessarily correlate with the logic of economics and conventional consumption. This is a complex issue because it is related to such a policy that contains many implicit factors that fall out of a possible analysis, at least measure within the framework of philosophical consideration.

But this issue is also interesting in the sense that this can become a factor in the development of the civil economics, as it used to be. However, limiting factors are also seen here, such as budget constraints and the same planning horizon.

Thus, we see possible limits of the acceleration of technological growth and, if we follow examples from natural science, they are already nearby.

Probably, the forecasts of acceleration will come true, but knowledge of the laws of nature tells us the existence of the limits of this phenomenon. Proceeding from this knowledge, it can be predicted that the speed of change will not become infinite, since this contradicts common sense and the possibilities of human adaptation, hence saturation is inevitable.

\section{The timing of the onset of the saturation phase}

Since, firstly, we have already crossed the line beyond which significant changes take place during the lifetime of one generation, and secondly, the development of science and technology continues to accelerate before our eyes, despite the fact that we see acceleration and assume its continuation in the future, both of these factors together mean a 
slowdown, which either will happen soon, or it will become clearly visible that it is already happening.

This will be another reality, where acceleration will cease, and the speed will become stable, ceasing to grow. This does not mean that progress will stop. This is a continuation of development with already achieved speed, with the speed that a person can "tolerate" within the framework of comfortable adaptability. This means that the world will continue to change with a huge, already achieved speed.

\section{The acceleration limit is nearby}

It would seem that, according to the meditations on the possibility of a singularity represented above, there always are mechanisms in the world that restrain it. Similarly, in our opinion, there must also be mechanisms that restrain the infinite acceleration of the technological growth. By analogy with the processes in natural sciences, we can assume that this should happen in the observable future. If we return to the simplest but absolutely typical physical process, it is interesting to note that there is a time interval in which the changes occur according to an exponential law, and, accordingly, are characterized by a time constant $-\tau$. But this exponential growth continues not indefinitely, but over a limited number of $\tau$, with the retreat of these changes towards slowing down and complete stoppage and termination of these changes also occurs during a scale time of $2-3 \tau$.

It should be noted once again that for the observer at the peak of the development of events, there is no reason for predicting the deceleration and stopping of acceleration because everything changes before his eyes, the process is going on and there are no signs that the acceleration will soon stop - no. However, real examples from the natural sciences suggest the opposite. Considering this, we can assume that the acceleration ceases already after a period proportional to $2-3 \tau$.

This is an example of a correct prediction, which is absolutely unobvious. For an experienced naturalist, infinity is a sign of error, for it is typical for him to get a stop in the response of accelerating development. After all, if we do not know the laws of natural science $a$ priori and the observation takes place on the time interval in which the exponential growth is well-seen, then the observer may seem quite reasonable and even almost obvious idea that this growth will continue indefinitely, hence the predictions about the singularity. But how can an inexperienced observer presume that this exponential growth will be replaced by a complete cessation of it and this, by the way, will happen very soon? And why, if in a natural science such a picture of development is typical, then for the concept of scientific and technical progress such predictions about the coming apocalypse, about the singularity are characteristic? Why not, on the contrary, looking at the processes occurring in natural science, do not put forward the assumption that what we see is quickly (exponentially) after a while (in physical processes, as a rule, very short) will be replaced by slowing down and stopping completely?

\section{Conclusion}

Thus, it can be concluded that there are a danger and weak validity of predicting future development from the perspective of an inexperienced observer within the framework of events and making predictions based on the phenomenological picture fixed at the mo- 
ment, extrapolating the current trends, which leads to the assumption of singularity. The examples typical for the natural sciences show that if something increases with acceleration, this does not mean at all that acceleration will take place perpetually. On the contrary, it often happens that these processes slow down and, reaching a certain speed, cease to grow.

It only needs to be noted that the process does not stop there. Saturation means only the stop of the acceleration of progress. Progress will continue with gathered huge speed.

We consider it important to deal with the nature of things, which, perhaps, will increase the chance to make at least some correct prediction.

\section{References}

1. Shestakova I.G. Analiz sovremennykh tendentsii nauchno-tekhnicheskogo progressa i gorizonty planirovaniia [Analysis of Current Trends in Scientific and Technical Progress and the Horizons of Planning]. Ekonomika i ekologicheskii menedzhment, 2013, no.1, pp. 67-79. (In Russian)

2. Kurzweil R. The Singularity is Near. New York: Viking Books, 2005. 652 p.

3. Vindzh V. Technological Singularity. Available at: https://www.frc.ri.cmu.edu/ hpm/book98/com.ch1/ vinge.singularity.html (accessed: 02.01.2014).

4. Kutyrev V. A. Vremia Mortido [The Time of Mortido (in the middle of the Body of Thought)]. St. Petersburg, Aleteiia, 2012.336 p. (In Russian)

5. Kutyrev V. A. Chelovecheskoe i inoe: bor'ba mirov [Human and other: the struggle of the worlds]. St. Petersburg, Aleteiia, 2009. 264 p. (In Russian)

6. Panov A. D. Tekhnologicheskaia singuliarnost', teorema Penrouza ob iskusstvennom intellekte i kvantovaia priroda soznaniia [Technology singularity, Penrose's theorem on artificial intelligence and the quantum nature of consciousness]. Metafizika, 2013, no. 3, pp. 141-188. (In Russian)

7. Shestakova I.G. Neogranichennoe nauchno-tekhnicheskoe razvitie i ego fundamental'nye predely [Unlimited scientific and technical development and its fundamental limits]. XXI vek: itogi proshlogo i problemy nastoiashchego plius, 2014, no. 4, pp. 47-51. (In Russian)

8. Laplace P.-S. Essai philosophique sur les probabilités. Paris, Bachelier, 1840. 294 p. (In French)

9. Malthus T.R. An Essay on the Principle of Population, (1798). Available at: http://www.econlib.org/ library/Malthus/malPop.html (accessed: 23.12.2015).

10. Hegel G. Lektsii po filosofii istorii [Lectures on the philosophy of history]. St. Petersburg, Nauka, 1993. 480 p. (In Russian)

11. Kont O. Kurs polozhitel'noi filosofii [Course of positive philosophy]. Vol. 1. St. Petersburg, Knizhnyi magazin Tovarishchestva "Posrednik", 1900. 176 p. (In Russian)

12. Lenin V.I. Tri istochnika i tri sostavnykh chasti marksizma [Three Sources and Three Components of Marxism]. Lenin V. I. Polnoe sobranie sochinenii [Collected works], vol. 23, Moscow, Nauka, 1967, pp. 4452. (In Russian)

13. Marx K., Engels F. Feierbakh. Protivopolozhnost' materialisticheskogo i idealisticheskogo vozzrenii [Feuerbach. Opposition of the Materialist and Idealist Outlook]. Moscow, Progress Publ., 1966, pp. 51-52. (In Russian)

14. Mechnikov L. Tsivilizatsiia i velikie istoricheskie reki [Civilization and the great historical rivers]. Moscow, Pangeia, 1995. 461 p. (In Russian)

15. Montesquieu S. O dukhe zakonov [On the spirit of laws]. Moscow, Mysl', 2011. 800 p. (In Russian)

16. Panarin V.I. Ritmy obshchestvennogo razvitiia i perekhod k postmodernu [Rhythms of Social Development and the Transition to Postmodern]. Voprosy filosofi, 1998, no. 8, pp. 24-40. (In Russian)

17. Engels F. Anti-Duhring. Marx K., Engels F. Sochineniia [Collected works], vol. 20. Moscow, Gosudarstvennoe izdatel'stvo politicheskoi literatury, 1961, pp. 10-44. (In Russian)

18. Rabbit Problems in Australia. Available at: http://www.animalcontrol.com.au/rabbit.htm (accessed: 23.12.2016).

19. Invazivnye chuzherodnye vidy: obzor rabot po invazivnym chuzherodnym vidam i soobrazheniia kasatel'no dal'neishei raboty [Invasive alien species: review of invasive alien species and considerations for future work]. Konferentsiia storon konventsii o biologicheskom raznoobrazii. Pkhenchkhan, Respublika Koreia, 6-17 oktiabria 2014 goda [The Conference of the Parties to the Convention on Biological Diversity, Pyeongchang, Republic of Korea, 6-17 octobre 2014]. Available at: https://www.cbd.int/doc/decisions/cop-12/ cop-12-dec-17-ru.doc (accessed: 23.12.2016). (In Russian) 
20. Smith A. An Inquiry into the Nature and Causes of the. Wealth of Nations, vol. 1, London, Methuen, 1904. $687 \mathrm{p}$.

21. Medvedev D. A. Sverkhtekhnologii i obshchestvo v XXI veke. Kurs lektsii. Vidiolektsiia 10. Tekhnologicheskaia singuliarnost' [Over-technology and society in the XXI century. Course of lectures. Video lecture 10. Technological singularity]. Available at: http://univertv.ru/video/sociologiya/sverhtehnologii_i_ obwestvo_v_21_veke/lekciya_10_tehnologicheskaya_singulyarnost (accessed: 21.12.2015). (In Russian)

22. Leontiev K. N. Srednii evropeets kak ideal i orudie vsemirnogo razrusheniia [The Middle European as an Ideal and the Tool of World-wide Destruction]. Leontiev K. N. Sobranie sochinenii [Collected Works], in 9 vols. Vol. 6. Moscow, V. M. Sablin Publ., 1912, pp. 40-127. (In Russian)

23. Meadows D. L. The Limits to Growth: A Report for the Club of Rome's Project on the Predicament of Mankind. New York, Universe Books, 1972. 211 p.

24. Ukaz Prezidenta RF ot 5 dekabria 2016 g. N 646 "Ob utverzhdenii Doktriny informatsionnoi bezopasnosti Rossiiskoi Federatsii" [Decree of the President of the Russian Federation of December 5, 2016 No. 646 "On the Approval of the Doctrine of Information Security of the Russian Federation"]. Available at: http://www. garant.ru/hotlaw/federal/1036728/ (accessed: 23.12.2016). (In Russian)

Received: 01.02.2018

Accepted: 10.05 .2018

Author's information:

Irina Shestakova — PhD, Visiting professor; irina_shestakova9@icloud.com

\section{К вопросу о пределах прогресса: возможна ли сингулярность?}

\section{И. Г.Шестакова}

Университет Норвич, 158, Гармон Драйв, Нортфилд, США, 05663

Для цитирования: Shestakova I. G. To the question of the limits of progress: Is singularity possible? // Вестник Санкт-Петербургского университета. Философия и конфликтология. 2018. Т. 34. Вып. 3. С. 391-401. https://doi.org/10.21638/11701/spbu17.2018.307

Статья посвящена рассмотрению одной из распространенных в философии рубежа XX-XXI вв. идей - о том, что экспоненциальный рост скорости прогресса переходит в технологическую сингулярность. Применяя научный подход, автор замечает, что переход процессов, характеризующихся экспоненциальным ускорением на начальных своих этапах, в фазу насыщения типичен в естествознании. Это позволяет наглядно представить, что процесс возрастания с ускорением, наблюдаемый на протяжении некоторого времени, не будет продолжаться бесконечно. Напротив, во многих случаях это означает скорый выход на плато скорости. Автор задается вопросом: если в естествознании типична подобная картина развития, почему для наших рефлексий на тему научно-технического прогресса характерны предсказания об апокалиптическом его завершении, о технологической сингулярности? Почему бы, наоборот, глядя на процессы, происходящие в естествознании, не выдвинуть предположение, что наблюдаемая картина ускорения научно-технического прогресса через некоторое время (в физических процессах, как правило, весьма короткое) сменится замедлением и полной остановкой? Возможные механизмы торможения ускорения развития инфокоммуникаций в целом просматриваются как в адаптационных возможностях самого человека, так и в приближающихся горизонтах планирования. Специфика обнаруживается в вопросе инвестиций в ВПК, представляющих собой локомотив для прогресса в гражданской сфере. При этом, несмотря на возможное в обозримом будущем прекращение/затухание ускорения прогресса науки и техники, сам прогресс и, как следствие, социальные 
трансформации не остановятся и даже не замедлятся - они продолжатся с достигнутой (возможно, огромной) скоростью, которая станет постоянной.

Ключевые слова: социальная философия, научно-технический прогресс, инфокоммуникации, скорость развития, горизонт планирования, экспонента, сингулярность, детерминизм, пределы прогресса.

Контактная информация:

Шестакова Ирина Григорьевна - приглашенный профессор; irina_shestakova9@icloud.com 